\title{
What does the Meadowlark say?
}

\section{By ROSE McLAUGHLIN, Indian Head}

What does the meadowlark say? When we were youngsters our favorite interpretations were, "My home is in Peterborough," and "I see your yellow petticoat." Sometimes he sang a shorter song, and then we thought he was saying, "I was here a year ago." One year we had a teacher called Miss Micklebust, and then all the meadowlarks began to sing, "Here comes Miss Micklebust."

In W. O. Mitchell's Saskatchewan novel, "Who Has Seen The Wind," the meadowlarks say, "One, two, three, and here I go," while in Mrs. Clarissa Stewart's poem in the last Blue Jay they say, "There's nothing here to kick about."

It set me to wondering just how many interpretations there are for the meadowlark's song, so at our annual meeting in October I asked a lot of people, and sure enough, everyone gave me a different answer.

"Which call do you mean?" asked Ralph Stueck. He whistled a long call, and a short, jerky one, and gave as his interpretation, "The bulls are in the wheat again," and "Three pretty preachers, three."

Then he turned to W. A. Brownlee of Rose Valley. "What does the meadowlark say when he starts to sing first thing in the morning?"

"First comes your little petticoat," replied Brownlee, logically enough.

"I was at Buckingham Palace," said a voice on the edge of the group, but it turned out that the speaker, a Miss Reid of Regina, was telling a friend about her trip to the British Isles, and not giving her version of the meadowlark's song at all!

Mrs. Wolters of Tolland, Alberta and she came all the way for no other reason than to attend the meeting-submitted, "We are very happy people."

Mrs. Hilda Newton of Indian Head said that in the homesteading days their uncle used to tell them that the meadowlark was supervising seeding operations, and telling them to "Put in 40 acres, Bob."

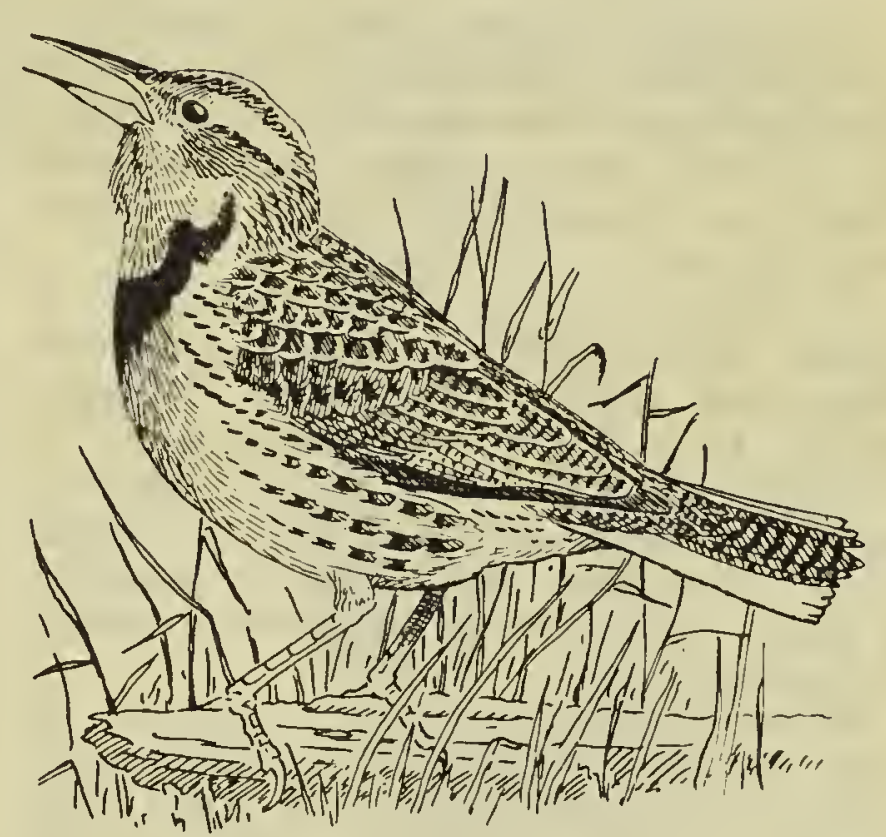

Some other are as follows:

Doug Gilroy: "Spring is here, you know," and "This place isn't suitable." Presumably the latter is the lady lark crabbing about the housing situation.

Bob Arnold of Prince Albert: "Somebody's pinching me."

Fred Bard: "Don't say you did if you didn't, you know."

Stuart Houston: "Oh dear, my feet are cold."

Myself, I think the meadowlark says, "You are my little sweetieheart." Singing to his lady love, what else would he be saying?

\section{AN APPRECIATION}

To read of a one-day count of 86 species of birds by the Speirs, the "Trumpeter Swan" and the "Memorable Experience" in seeing Whooping Cranes - all this and the heavenly pictures too, of the latter! What more could one ask? I must express my appreciation for this magazine.

I hope the boy who first observed the Cranes, and told his father will be suitably rewarded.

Mrs. Olive Simmons, White Rock, B.C. 